\title{
Renormalization of Mass Flow Data in FCDPs for Thermal Efficiency Variation
}

Fuel Cycle Research \& Development

Prepared for U.S. Department of Energy Fuel Cycle Options Campaign

T. A. Taiwo and T. K. Kim May 30, 2013 ANL-FCT-334 


\section{DISCLAIMER}

This information was prepared as an account of work sponsored by an agency of the U.S. Government. Neither the U.S. Government nor any agency thereof, nor any of their employees, makes any warranty, expressed or implied, or assumes any legal liability or responsibility for the accuracy, completeness, or usefulness, of any information, apparatus, product, or process disclosed, or represents that its use would not infringe privately owned rights. References herein to any specific commercial product, process, or service by trade name, trade mark, manufacturer, or otherwise, does not necessarily constitute or imply its endorsement, recommendation, or favoring by the U.S. Government or any agency thereof. The views and opinions of authors expressed herein do not necessarily state or reflect those of the U.S. Government or any agency thereof. 
Report Sign-off Page

\section{Submitted by}

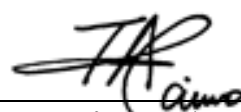

Temitope A. Taiwo

FCO ANL Lead

Argonne National Laboratory

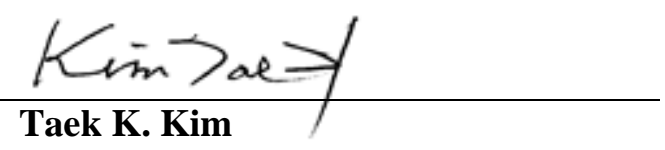

May 30, 2013

Taek K. Kim

May 30, 2013

FCDP Development Team Leader

Argonne National Laboratory

\section{Approved by}

\section{Date}

\section{Date}

\section{Michael Todosow}

Date

FCO E\&S Team

Brookhaven National Laboratory

May 30, 2013

\section{Roald Wigeland}

Date

\section{FCO NTD}

Idaho National Laboratory 
(This page was left blank intentionally) 


\section{FUEL CYCLE OPTIONS CAMPAIGN}

\section{RENORMALIZATION OF MASS FLOW DATA IN FCDPS FOR THERMAL EFFICIENCY VARIATION}

\section{INTRODUCTION}

The 40 Fuel Cycle Data Packages (FCDPs) [1] to be used for the 2013 Evaluation and Screening (E\&S) of Fuel Cycle Options have been developed using assumptions [2] for the thermal efficiencies of the reactors in the different stages of the representative fuel cycle options for the 40 Evaluation Groups (EGs). Due to considerations about the potential for these different thermal efficiencies to bias the E\&S results and maybe misinform readers, it has been requested to re-normalize mass flow data using the uniform thermal efficiency values for two additional sensitivity study cases. These cases are:

1. Renormalization using thermal efficiency value of $33 \%$ for all the reactors in a representative option.

2. Renormalization using thermal power (GWt) rather than electricity generation (GWe) for all the reactors in a representative option (corresponding to artificial weighting of the fuel cycle data using a turbine thermal efficiency of 100\%).

It is noted that the thermal efficiency of any given External Driven System (EDS) has been adjusted separately for the transmuter (e.g., sub-critical blanket) and the overall system because a significant fraction of the power generated is used to support the system components, e.g., the accelerator in an EDS. The effective thermal efficiency values for the externally driven systems are provided in Table 1.

This memo documents the approach and results for the renormalization of the mass flow data contained in FCDPs.

\section{APPROACH}

Because physics considerations provide the basis for determining the power sharing to achieve the mass balance between different stages of the fuel cycle options, it is evident that in going from the data in the existing FCDPs to those for each of the two sensitivity study cases above, a common renormalization factor can be applied to the Mass Flow Data table of each of the FCDPs to get the re-normalized masses. To provide assurance about this principle, formulas have been derived to demonstrate that a single renormalization factor is required. Appendix A is the derivation of the formulas required to change the power sharing values and the renormalization factor value for the mass flow data tables. These formulas were validated by using the calculation approach for a representative option. The general forms of the formulas are

$$
\begin{aligned}
& F_{k}^{n}=\frac{\omega_{k}}{\sum_{i} \omega_{i} F_{i}^{o}} F_{k}^{o}, \\
& M_{k}^{n}=\frac{1}{\sum_{i} \omega_{i} F_{i}^{o}} M_{k}^{o},
\end{aligned}
$$


where the superscripts of " $n$ " and " $o$ " indicate the new and original thermal efficiencies, respectively, and the subscript denotes the stage number, and

$\boldsymbol{F}_{\boldsymbol{k}}^{\boldsymbol{n}}$ = Power-sharing fraction of k-th stage with new thermal efficiency,

$\boldsymbol{F}_{\boldsymbol{k}}^{o} \quad=$ Power-sharing fraction of k-th stage with original thermal efficiency,

$\boldsymbol{M}_{\boldsymbol{k}}^{n}=$ Mass data of k-th stage in Mass Flow Data table of FCDP with new thermal efficiency,

$\boldsymbol{M}_{k}^{\boldsymbol{o}}=$ Mass data of k-th stage in Mass Flow Data table of FCDP with original thermal efficiency,

$\boldsymbol{\omega}_{\boldsymbol{k}}=$ New to original thermal efficiency ratio of stage $\mathrm{k}\left(=\boldsymbol{\eta}_{\boldsymbol{k}}^{n} / \boldsymbol{\eta}_{\boldsymbol{k}}^{\boldsymbol{o}}\right)$.

\section{Results}

These equations have been applied to the FCDPs for the 40 Evaluation Groups and the results for the new power sharing and renormalization values are summarized in Table 2. The table includes the

- $\quad$ EG group name (e.g., EG01/OT01A)

- Columns for pertinent data from the FCDPs (power sharing and thermal efficiency values)

- Columns for the uniform thermal efficiency of 33\% (power sharing and renormalization values)

- Columns for thermal power generation weighting (power sharing and renormalization).

\section{Application of the Results}

The information provided in Table 2 can be used in the following way to derive the mass flow data for the two variations:

- The new power-sharing fractions for a given thermal efficiency variation are obtained directly from Table 2.

- $\quad$ To re-normalize the mass flow data for either a thermal efficiency of 33\% or thermal power (GWt), use the renormalization factor given in Table 2 to multiple the mass flow data information entries contained in the Mass Flow Data table of FCDP file for the representative option of an Evaluation Group.

\section{References}

1. T. K. Kim, E. Hoffman, T. A. Taiwo, "Completion of Fuel Cycle Data Package System Datasheets for 2013 Evaluation and Screening,” Argonne National Laboratory, ANL-FCT-333, FCRD-FCO-2013-000165, May 30, 2013.

2. “Assumption for Nuclear Energy Systems Analyses, Revision 3,” FCRD-FCO-2012-000026, January15, 2013. 
Table 1. Effective Thermal Efficiency Values of External Driven Systems

\begin{tabular}{|c|c|c|c|c|}
\hline $\begin{array}{l}\text { Option } \\
\text { number }\end{array}$ & Design parameter & FCDP Data & $\begin{array}{l}\text { Renormalization } \\
\text { using thermal } \\
\text { efficiency of } 33 \%\end{array}$ & $\begin{array}{c}\text { Renormalization } \\
\text { using thermal } \\
\text { power }{ }^{\text {b) }}\end{array}$ \\
\hline \multirow{5}{*}{ EG06 } & Stage & \multicolumn{3}{|c|}{1} \\
\hline & Thermal power, MWt & \multicolumn{3}{|c|}{2441.0} \\
\hline & Required electricity, MWe ${ }^{\text {a) }}$ & \multicolumn{3}{|c|}{195.0} \\
\hline & Thermal efficient, \% & 44.4 & 33.0 & 100.0 \\
\hline & Effective thermal efficiency, \% & 36.41 & 25.01 & 92.01 \\
\hline \multirow{5}{*}{ EG07 } & Stage & \multicolumn{3}{|c|}{1} \\
\hline & Thermal power, MWt & \multicolumn{3}{|c|}{1000.0} \\
\hline & Required electricity, MWe & \multicolumn{3}{|c|}{123.0} \\
\hline & Thermal efficient, \% & 40.0 & 33.0 & 100.0 \\
\hline & Effective thermal efficiency, \% & 27.70 & 20.70 & 87.70 \\
\hline \multirow{5}{*}{ EG08 } & Stage & \multicolumn{3}{|c|}{1} \\
\hline & Thermal power, $\mathrm{MWt}$ & \multicolumn{3}{|c|}{2000.0} \\
\hline & Required electricity, MWe & \multicolumn{3}{|c|}{195.0} \\
\hline & Thermal efficient, \% & 43.0 & 33.0 & 100.0 \\
\hline & Effective thermal efficiency, \% & 33.25 & 23.25 & 90.25 \\
\hline \multirow{5}{*}{ EG16 } & Stage & \multicolumn{3}{|c|}{2} \\
\hline & Thermal power, MWt & \multicolumn{3}{|c|}{840.0} \\
\hline & Required electricity, MWe & \multicolumn{3}{|c|}{84.9} \\
\hline & Thermal efficient, \% & 40.0 & 33.0 & 100.0 \\
\hline & Effective thermal efficiency, \% & 29.89 & 22.89 & 89.89 \\
\hline \multirow{5}{*}{ EG33 } & Stage & \multicolumn{3}{|c|}{1} \\
\hline & Thermal power, MWt & \multicolumn{3}{|c|}{840.0} \\
\hline & Required electricity, MWe & \multicolumn{3}{|c|}{46.0} \\
\hline & Thermal efficient, \% & 40.0 & 33.0 & 100.0 \\
\hline & Effective thermal efficiency, \% & 34.52 & 27.52 & 94.52 \\
\hline \multirow{5}{*}{ EG34 } & Stage & \multicolumn{3}{|c|}{1} \\
\hline & Thermal power, MWt & \multicolumn{3}{|c|}{840.0} \\
\hline & Required electricity, MWe & \multicolumn{3}{|c|}{43.68} \\
\hline & Thermal efficient, \% & 40.0 & 33.0 & 100.0 \\
\hline & Effective thermal efficiency, \% & 34.80 & 27.80 & 94.80 \\
\hline \multirow{5}{*}{ EG35 } & Stage & \multicolumn{3}{|c|}{2} \\
\hline & Thermal power, MWt & & 840.0 & \\
\hline & Required electricity, MWe & & 75.0 & \\
\hline & Thermal efficient, \% & 40.0 & 33.0 & 100.0 \\
\hline & Effective thermal efficiency, \% & 31.07 & 24.07 & 91.07 \\
\hline & Stage & & 2 & \\
\hline & Thermal power, MWt & & 840.0 & \\
\hline EG36 & Required electricity, MWe & & 42.0 & \\
\hline & Thermal efficient, \% & 40.0 & 33.0 & 100.0 \\
\hline & Effective thermal efficiency, \% & 35.00 & 28.00 & 95.00 \\
\hline
\end{tabular}

a) Required electricity to support components of an External Driven System (e.g., accelerator).

b) Artificial thermal efficiency value. 
Table 1. Effective Thermal Efficiency Values of External Driven Systems (Continued)

\begin{tabular}{|l|l|c|c|c|}
\hline \multirow{2}{*}{$\begin{array}{c}\text { Option } \\
\text { number }\end{array}$} & Design parameter & FCDP Data & $\begin{array}{c}\text { Renormalization } \\
\text { using thermal } \\
\text { efficiency of 33\% }\end{array}$ & $\begin{array}{c}\text { Renormalization } \\
\text { using thermal } \\
\text { power }\end{array}$ \\
\hline \multirow{4}{*}{ EG39 } & Stage & \multicolumn{3}{|c|}{3} \\
\cline { 2 - 5 } & Thermal power, MWt & \multicolumn{3}{|c|}{840.0} \\
\cline { 2 - 5 } & Required electricity, MWe & 40.0 & 33.0 & 120.0 \\
\cline { 2 - 5 } & Thermal efficient, \% & 25.71 & 18.71 & 85.71 \\
\cline { 2 - 5 } & Effective thermal efficiency, \% & \multicolumn{3}{|c|}{1} \\
\hline \multirow{4}{*}{ EG40 } & Stage & \multicolumn{3}{|c|}{611.25} \\
\cline { 2 - 5 } & Thermal power, MWt & \multicolumn{3}{|c|}{100.0} \\
\cline { 2 - 5 } & Required electricity, MWe & 40.0 & 33.0 & 100.0 \\
\cline { 2 - 5 } & Thermal efficient, \% & 23.64 & 16.64 & 83.64 \\
\cline { 2 - 5 } & Effective thermal efficiency, \% & \multicolumn{3}{|c|}{} \\
\hline
\end{tabular}


Table 2. Power-sharing Fractions and Mass Renormalization Factor for Thermal Efficiency of $33 \%$ and Thermal Power (GWt) for 40 Evaluation Groups

\begin{tabular}{|c|c|c|c|c|c|c|c|c|c|c|c|c|c|c|}
\hline \multirow{3}{*}{$\begin{array}{l}\text { Thermal } \\
\text { efficiency } \\
\text { variation } \\
\text { Stage }\end{array}$} & \multicolumn{6}{|c|}{ Thermal efficiencies in FCDP System Datasheet } & \multicolumn{4}{|c|}{$\begin{array}{c}\text { Renormalization using thermal } \\
\text { efficiency of } 33 \%\end{array}$} & \multicolumn{4}{|c|}{$\begin{array}{c}\text { Renormalization using thermal } \\
\text { power }\end{array}$} \\
\hline & \multicolumn{3}{|c|}{$\begin{array}{l}\text { Original thermal } \\
\text { efficiency, \% }\end{array}$} & \multicolumn{3}{|c|}{$\begin{array}{l}\text { Power sharing } \\
\text { fraction , \% }\end{array}$} & \multicolumn{3}{|c|}{$\begin{array}{l}\text { Power sharing } \\
\text { fraction, } \%\end{array}$} & \multirow{2}{*}{$\begin{array}{c}\text { Mass } \\
\text { renormal } \\
\text { ization } \\
\text { factor }\end{array}$} & \multicolumn{3}{|c|}{$\begin{array}{l}\text { Power sharing } \\
\text { fraction, } \%\end{array}$} & \multirow{2}{*}{$\begin{array}{c}\text { Mass } \\
\text { renormal } \\
\text { ization } \\
\text { factor }\end{array}$} \\
\hline & 1 & 2 & 3 & 1 & 2 & 3 & 1 & 2 & 3 & & 1 & 2 & 3 & \\
\hline EG01/OT01A & 33 & & & 100.0 & & & 100.0 & & & 1.000 & 100.0 & & & 0.330 \\
\hline EG02/OT01B & 50 & & & 100.0 & & & 100.0 & & & 1.515 & 100.0 & & & 0.500 \\
\hline EG03/OT01C & 33 & & & 100.0 & & & 100.0 & & & 1.000 & 100.0 & & & 0.330 \\
\hline EG04/OT02 & 40 & & & 100.0 & & & 100.0 & & & 1.212 & 100.0 & & & 0.400 \\
\hline EG05/OT03 & 50 & & & 100.0 & & & 100.0 & & & 1.515 & 100.0 & & & 0.500 \\
\hline EG06/OT04 & 36.4 & & & 100.0 & & & 100.0 & & & 1.456 & 100.0 & & & 0.396 \\
\hline EG07/OT05 & 27.7 & & & 100.0 & & & 100.0 & & & 1.338 & 100.0 & & & 0.316 \\
\hline EG08/OT06 & 33.25 & & & 100.0 & & & 100.0 & & & 1.430 & 100.0 & & & 0.368 \\
\hline EG09/SL01 & 40 & & & 100.0 & & & 100.0 & & & 1.212 & 100.0 & & & 0.400 \\
\hline EG10/SL02 & 44.4 & & & 100.0 & & & 100.0 & & & 1.345 & 100.0 & & & 0.444 \\
\hline EG11/SL03 & 40 & & & 100.0 & & & 100.0 & & & 1.212 & 100.0 & & & 0.400 \\
\hline EG12/ML01 & 33 & 33 & & 76.1 & 23.9 & & 76.1 & 23.9 & & 1.000 & 76.1 & 23.9 & & 0.330 \\
\hline EG13/ML02 & 33.3 & 33.3 & & 90.2 & 9.8 & & 90.2 & 9.8 & & 1.009 & 90.2 & 9.8 & & 0.333 \\
\hline EG14/ML03 & 40 & 33 & & 70.6 & 29.4 & & 66.5 & 33.5 & & 1.141 & 66.5 & 33.5 & & 0.377 \\
\hline EG15/ML04 & 33 & 40 & & 88.1 & 11.9 & & 90.0 & 10.0 & & 1.021 & 90.0 & 10.0 & & 0.337 \\
\hline EG16/ML05 & 33 & 29.9 & & 92.6 & 7.4 & & 94.2 & 5.8 & & 1.018 & 92.6 & 7.4 & & 0.330 \\
\hline EG17/ML06 & 33 & 33 & & 90.5 & 9.5 & & 90.5 & 9.5 & & 1.000 & 90.5 & 9.5 & & 0.330 \\
\hline EG18/ML07 & 33 & 33 & & 68.7 & 31.3 & & 68.7 & 31.3 & & 1.000 & 68.7 & 31.3 & & 0.330 \\
\hline EG19/SC01 & 33 & & & 100.0 & & & 100.0 & & & 1.000 & 100.0 & & & 0.330 \\
\hline EG20/SC02 & 33 & & & 100.0 & & & 100.0 & & & 1.000 & 100.0 & & & 0.330 \\
\hline EG21/SC03 & 33.3 & & & 100.0 & & & 100.0 & & & 1.009 & 100.0 & & & 0.333 \\
\hline EG22/SC04 & 33.3 & & & 100.0 & & & 100.0 & & & 1.009 & 100.0 & & & 0.333 \\
\hline EG23/SC05 & 40 & & & 100.0 & & & 100.0 & & & 1.212 & 100.0 & & & 0.400 \\
\hline EG24/SC06 & 40 & & & 100.0 & & & 100.0 & & & 1.212 & 100.0 & & & 0.400 \\
\hline EG25/SC07 & 33 & & & 100.0 & & & 100.0 & & & 1.000 & 100.0 & & & 0.330 \\
\hline
\end{tabular}


Table 2. Power-sharing Fractions and Mass Renormalization Factor for Thermal Efficiency of $33 \%$ and Thermal Power (GWt) for 40 Evaluation Groups (Continued)

\begin{tabular}{|c|c|c|c|c|c|c|c|c|c|c|c|c|c|c|}
\hline \multirow{3}{*}{$\begin{array}{l}\text { Thermal } \\
\text { efficiency } \\
\text { variation } \\
\text { Stage }\end{array}$} & \multicolumn{6}{|c|}{ Thermal efficiencies in FCDP System Datasheet } & \multicolumn{4}{|c|}{$\begin{array}{c}\text { Renormalization using thermal } \\
\text { efficiency of } 33 \%\end{array}$} & \multicolumn{4}{|c|}{$\begin{array}{c}\text { Renormalization using thermal } \\
\text { power }\end{array}$} \\
\hline & \multicolumn{3}{|c|}{$\begin{array}{l}\text { Original thermal } \\
\text { efficiency }\end{array}$} & \multicolumn{3}{|c|}{$\begin{array}{l}\text { Power sharing } \\
\text { fraction, } \%\end{array}$} & \multicolumn{3}{|c|}{$\begin{array}{c}\text { Power sharing } \\
\text { fraction, \% }\end{array}$} & \multirow{2}{*}{$\begin{array}{c}\text { Mass } \\
\text { renormal } \\
\text { ization } \\
\text { factor } \\
\end{array}$} & \multicolumn{3}{|c|}{$\begin{array}{l}\text { Power sharing } \\
\text { fraction, } \%\end{array}$} & \multirow{2}{*}{$\begin{array}{c}\text { Mass } \\
\text { renormal } \\
\text { ization } \\
\text { factor }\end{array}$} \\
\hline & 1 & 2 & 3 & 1 & 2 & 3 & 1 & 2 & 3 & & 1 & 2 & 3 & \\
\hline EG26/SC08 & 44.4 & & & 100.0 & & & 100.0 & & & 1.345 & 100.0 & & & 0.444 \\
\hline EG27/SC09 & 40 & & & 100.0 & & & 100.0 & & & 1.212 & 100.0 & & & 0.400 \\
\hline EG28/SC10 & 40 & & & 100.0 & & & 100.0 & & & 1.212 & 100.0 & & & 0.400 \\
\hline EG29/MC01 & 40 & 33 & & 61.1 & 38.9 & & 56.4 & 43.6 & & 1.120 & 56.4 & 43.6 & & 0.370 \\
\hline EG30/MC02 & 40 & 33 & & 87.0 & 13.0 & & 84.7 & 15.3 & & 1.180 & 84.7 & 15.3 & & 0.389 \\
\hline EG31/MC03 & 33 & 40 & & 68.2 & 31.8 & & 72.2 & 27.8 & & 1.059 & 72.2 & 27.8 & & 0.349 \\
\hline EG32/MC04 & 33 & 40 & & 63.4 & 36.6 & & 67.8 & 32.2 & & 1.068 & 67.8 & 32.2 & & 0.353 \\
\hline EG33/MC05 & 34.5 & 33 & & 83.7 & 16.3 & & 80.4 & 19.6 & & 1.204 & 82.3 & 17.7 & & 0.359 \\
\hline EG34/MC06 & 34.8 & 33 & & 80.0 & 20.0 & & 76.2 & 23.8 & & 1.192 & 78.2 & 21.8 & & 0.359 \\
\hline EG35/MC07 & 33 & 31.1 & & 84.7 & 15.3 & & 87.7 & 12.3 & & 1.036 & 85.1 & 14.9 & & 0.332 \\
\hline EG36/MC08 & 33.3 & 35 & & 93.5 & 6.5 & & 94.7 & 5.3 & & 1.022 & 94.1 & 5.9 & & 0.335 \\
\hline EG37/MC09 & 33.3 & 40.0 & 32.4 & 11.9 & 50.1 & 38 & 12.8 & 45.0 & 42.2 & 1.088 & 12.8 & 45.0 & 42.2 & 0.359 \\
\hline EG38/MC10 & 40 & 33 & & 85.5 & 14.5 & & 83.0 & 17.0 & & 1.176 & 83.0 & 17.0 & & 0.388 \\
\hline EG39/MC11 & 33 & 33 & 26 & 69.6 & 24.3 & 6.02 & 70.8 & 24.8 & 4.4 & 1.017 & 69.3 & 24.2 & 6.5 & 0.328 \\
\hline EG40/MC12 & 23.6 & 33 & & 20.5 & 79.5 & & 15.4 & 84.6 & & 1.064 & 23.2 & 76.8 & & 0.319 \\
\hline
\end{tabular}




\section{Appendix A: Derivation of Renormalization Formulas for Thermal Efficiency Variation}

In this Appendix, the formulas of the power-sharing fraction of each stage and the common renormalization factor from the variation of the thermal efficiency are derived from the mass balance relationship in a typical two-stage fuel cycle option, but the derived formulas can be generalized to any number of stages in a fuel cycle option.

\section{Transforming the Power Sharing}

The relationship between the mass flow data per unit thermal power generation and electricity energy generation is

$$
\hat{M}=\eta \dot{M}
$$

where

$$
\begin{aligned}
& \eta=\text { Thermal efficiency of nuclear system, } \\
& \hat{M}=\text { Mass flow data per unit thermal power generation, t/GWt-yr, } \\
& \dot{M}=\text { Mass flow data per unit electricity energy generation, } \mathrm{t} / \mathrm{GWe}-\mathrm{yr} \text {. }
\end{aligned}
$$

In a typical two-stage fuel cycle option, there is material exchange between the first and second stage systems: e.g., the first stage produces extra materials and the second stage consumes them. At the equilibrium state, the net production rate in the first stage should balance the net consumption rate in the second stage;

$$
\begin{aligned}
& F_{1}^{o} \times \dot{M}_{1}^{o}=F_{2}^{o} \times \dot{M}_{2}^{o}, \\
& F_{1}^{o}+F_{2}^{o}=1
\end{aligned}
$$

where, the superscript "o" indicates the values with the original thermal efficiency and

$F_{1}^{o} \quad=$ Fraction of power generation from the first stage.

$F_{2}^{o} \quad=$ Fraction of power generation from the second stage.

$\dot{M}_{1}^{o} \quad=$ Net production mass per unit electricity generation from the first stage (t/GWe-yr).

$\dot{\boldsymbol{M}}_{2}^{\boldsymbol{o}} \quad=$ Net consumption mass per unit electricity generation in the second stage (t/GWe-yr).

Similarly, the net production mass in the first stage should balance the net consumption mass in the second stage for the new thermal efficiencies,

$$
\begin{aligned}
& F_{1}^{n} \times \dot{M}_{1}^{n}=F_{2}^{n} \times \dot{M}_{2}^{n} \\
& F_{1}^{n}+F_{2}^{n}=1
\end{aligned}
$$

where the superscript " $n$ ” indicates the values with the $\boldsymbol{n e w}$ thermal efficiency. In Eq (1), the mass flow data per unit thermal power generation (i.e., the value of left hand side) does not vary per thermal efficiency, while the mass flow data per unit electricity energy generation varies. Based on Eq (1), one can show the following relationships between new and original mass flow data,

$$
\dot{M}_{1}^{n}=\frac{\eta_{1}^{o}}{\eta_{1}^{n}} \cdot \dot{M}_{1}^{o}
$$




$$
\dot{M}_{2}^{n}=\frac{\eta_{2}^{o}}{\eta_{2}^{n}} \cdot \dot{M}_{2}^{o}
$$

Using Eqs (6), (7) and (2), Eq (4) becomes

Using Eqs (5) and (8), one can derive

$$
\frac{F_{2}^{o}}{F_{1}^{o}} \times \frac{\eta_{1}^{o}}{\eta_{1}^{n}} F_{1}^{n}=\frac{\eta_{1}^{o}}{\eta_{1}^{n}} F_{2}^{n} .
$$

$$
\frac{\eta_{1}^{o}}{\eta_{1}^{n}} \frac{F_{2}^{o}}{F_{1}^{o}}=\left(\frac{\eta_{2}^{o}}{\eta_{2}^{n}}+\frac{F_{2}^{o}}{F_{1}^{o}} \times \frac{\eta_{1}^{o}}{\eta_{1}^{n}}\right) F_{2}^{n}
$$

Finally, one can derive the new fractions of electricity generation from the each stage,

$$
\begin{aligned}
& F_{1}^{n}=\frac{\frac{\eta_{1}^{n}}{\eta_{1}^{o}}}{\left(\frac{\eta_{1}^{n}}{\eta_{1}^{o}} F_{1}^{o}+\frac{\eta_{2}^{n}}{\eta_{2}^{o}} F_{2}^{o}\right)} F_{1}^{o}, \\
& F_{2}^{n}=\frac{\frac{\eta_{2}^{n}}{\eta_{2}^{o}}}{\left(\frac{\eta_{1}^{n}}{\eta_{1}^{o}} F_{1}^{o}+\frac{\eta_{2}^{n}}{\eta_{2}^{o}} F_{2}^{o}\right)} F_{2}^{o} .
\end{aligned}
$$

\section{Determination of a Common Renormalization Factor}

The mass flow values in the "Mass Flow Data" table in each FCDP are calculated based on the following equations for the original and new thermal efficiencies,

$$
\begin{aligned}
& M_{i, k}^{o}=C \cdot \dot{M}_{i, k}^{o} \times F_{i}^{o}, \\
& M_{i, k}^{n}=C \cdot \dot{M}_{i, k}^{n} \times F_{i}^{n},
\end{aligned}
$$

where $C$ is the normalization constant value to generate a certain amount of electricity. For the current FCDP template, the $C$ value was defined as 100 GWe-yr. The subscripts of $\mathrm{i}$ and k denote the stage number and material kind (such as U, Pu, NU, etc.), respectively. By inserting Eqs (10), (6), and (7) into Eq (12), one can derive the relationships between the mass flow values for the new and original thermal efficiencies,

$$
\begin{aligned}
M_{1, k}^{n} & =\frac{1}{\left(\frac{\eta_{1}^{n}}{\eta_{1}^{o}} F_{1}^{o}+\frac{\eta_{2}^{n}}{\eta_{2}^{o}} F_{2}^{o}\right)} M_{1, k}^{o} \\
M_{2, k}^{n} & =\frac{1}{\left(\frac{\eta_{1}^{n}}{\eta_{1}^{o}} F_{1}^{o}+\frac{\eta_{2}^{n}}{\eta_{2}^{o}} F_{2}^{o}\right)} M_{2, k}^{o}
\end{aligned}
$$


So far, the power-sharing fraction formula of Eq (10) and the mass renormalization formula of Eq (13) have been derived for a typical two-stage fuel cycle option. In conclusion, note that Eqs (13.a) and (13.b) indicate that the mass renormalization factor is the same across the FCDP Mass Flow Data table regardless of the stage and material kind.

\section{Generalized Form of Formulas}

The formulas of Eqs (10) and (13) could be generalized to any number of stage fuel cycle options such as

- Power-sharing fraction;

$$
F_{k}^{n}=\frac{\omega_{k}}{\sum_{i} \omega_{i} F_{i}^{o}} F_{k}^{o},
$$

- $\quad$ Mass renormalization factor;

$$
M_{k}^{n}=\frac{1}{\sum_{i} \omega_{i} F_{i}^{o}} M_{\bar{k}}^{o},
$$

where the subscript denotes the stage number, and

$$
\boldsymbol{\omega}_{\boldsymbol{k}}=\text { New to original thermal efficiency ratio of stage } \mathrm{k}\left(=\boldsymbol{\eta}_{\boldsymbol{k}}^{n} / \boldsymbol{\eta}_{k}^{o}\right) \text {. }
$$

\section{Validation of Formulas}

In order to validate the derived formulas, the power sharing fractions and mass flow data for the thermal power generation case were calculated to obtain the mass balances between the stages in the fuel cycle option and the results were compared to those obtained with the formulas of Eqs (14) and (15). This exercise was performed for the Evaluation Group of 37, which has the most complicated fuel cycle option among the current 40 representative fuel cycle options.

The representative fuel cycle option for EG37 consists of PWR(LEU) to SFR(TRU/U,Th) to PWR(U233/U). In this fuel cycle option, the TRU generated in all stages is recycled in stage 2 and the recovered uranium (mostly U-233) from the thorium blanket of stage 2 is used as the primary fissile material for stage 3. For this fuel cycle option, the loss rates during fuel fabrication and separations of $0.2 \%$ and $1.0 \%$ were assumed.

Table A.1 shows the summary of the core performance parameters. Using the given thermal efficiencies in Table A.1, the normalized mass flow rates per electricity generation for one year (i.e., t/GWe-yr) were calculated and provided in Table A.2. The equations to calculate the normalized mass flow data are introduced in the FCDP calculation note for the EG37 [A.1]. Similarly, the normalized mass flow rates per electricity generation for one year (i.e., t/GWe-year) were calculated by using an artificial uniform thermal efficiency of $100 \%$, which is equivalent to the mass flow data per thermal power generation for one year (i.e., t/GWt-yr). The results are provided in Table A.3. 
Table A.1 Summary of Core Performance and Mass Flow of Fuel Cycle Option

\begin{tabular}{|c|c|c|c|}
\hline & $\begin{array}{r}\text { Stage } 1 \\
\text { PWR (UOX) }\end{array}$ & $\begin{array}{r}\text { Stage } 2-\text { SFR } \\
\text { (TRU/U, Th) }\end{array}$ & $\begin{array}{r}\text { Stage } 3 \\
\text { PWR (U-233/U) }\end{array}$ \\
\hline Reactor Power, MW-thermal & 3000.0 & 3000.0 & 3400.0 \\
\hline Reactor Power, MW-electric & 1000.0 & 1200.0 & 1100.0 \\
\hline Thermal efficiency, \% & 33.3 & 40.0 & 32.4 \\
\hline Reactor Capacity Factor & 0.90 & 0.90 & 0.90 \\
\hline $\begin{array}{l}\text { Enrichment of fresh driver fuel, \% } \\
\text { U-235/U } \\
\text { U-233/HM } \\
\text { TRU/HM }\end{array}$ & $\begin{array}{r}4.21 \\
- \\
-\end{array}$ & $\begin{array}{r}- \\
- \\
28.6\end{array}$ & $\begin{array}{r}- \\
3.4 \\
-\end{array}$ \\
\hline Number of batches & 3 & $3-4$ & 3 \\
\hline Average burnup, \% & 5.21 & 4.90 & 5.66 \\
\hline Specific power density, MW/t & 33.7 & 31.2 & 37.3 \\
\hline Fuel residence time, year & 4.5 & $4.5-6.0$ & 4.5 \\
\hline Cycle length, year & 1.5 & 1.5 & 1.5 \\
\hline Fuel inventory, $\mathrm{t}$ & 89.05 & 96.23 & 91.14 \\
\hline HM charge per batch, $t$ & 29.68 & 30.00 & 30.38 \\
\hline HM discharge per batch, $\mathrm{t}$ & 28.14 & 28.53 & 28.66 \\
\hline $\begin{array}{l}\text { Average charge mass fraction, \% } \\
\text { Th } \\
\text { U-233+Pa-233 } \\
\text { U (other than U-233+Pa-233) } \\
\text { TRU }\end{array}$ & $\begin{array}{r}- \\
- \\
100.00 \\
0.00\end{array}$ & $\begin{array}{r}59.60 \\
- \\
28.80 \\
11.60 \\
\end{array}$ & $\begin{array}{r}- \\
3.42 \\
96.58 \\
-\end{array}$ \\
\hline $\begin{array}{l}\text { Average discharge mass fraction, \% } \\
\text { Th } \\
\text { U-233+Pa-233 } \\
\text { U (other than U-233+Pa-233) } \\
\text { TRU } \\
\text { FP }\end{array}$ & $\begin{array}{r}- \\
- \\
93.48 \\
1.31 \\
5.21\end{array}$ & $\begin{array}{r}56.00 \\
2.61 \\
26.22 \\
10.26 \\
4.91\end{array}$ & $\begin{array}{r}- \\
0.35 \\
92.71 \\
1.29 \\
5.66\end{array}$ \\
\hline
\end{tabular}


Table A.2 Normalized Mass Flow Rates per for Original Thermal Efficiency Values

\begin{tabular}{|l|r|r|r|}
\hline & Stage 1 & Stage 2 & Stage 3 \\
\hline Thermal efficiency, \% & PWR (UOX) & SFR (TRU/U, Th) & PWR (U-233/U) \\
\hline Natural resource, t/GWe-yr & & 40.0 & 32.5 \\
Th & - & 11.03 & - \\
U & 188.1 & - & - \\
\hline Charge mass, t/GWe-yr & & & \\
Th & - & 11.03 & - \\
U233+Pa233 & - & - & 0.70 \\
U (other than U233+Pa233) & 21.90 & 5.35 & 19.81 \\
TRU & 0.00 & 2.14 & - \\
\hline Discharge, t/GWe-yr & & & - \\
Th & - & 10.37 & 0.07 \\
U233+Pa233 & - & 0.48 & 19.02 \\
U (other than U233+Pa233) & 20.47 & 4.86 & 0.26 \\
TRU & 0.29 & 1.90 & 1.16 \\
FP & 1.14 & 0.91 & - \\
\hline Mass balance, t/GWe-yr & & & - \\
Th & - & -0.66 & -0.63 \\
U233+Pa233 & -1.43 & -0.48 & -0.79 \\
U (other than U233+Pa233) & 0.29 & -0.24 & 0.26 \\
TRU & 1.14 & 0.91 & 1.16 \\
FP & & & \\
\hline
\end{tabular}


Table A.3 Normalized Mass Flow Rates for Thermal Power Generation

\begin{tabular}{|l|r|r|r|}
\hline & Stage 1 & Stage 2 & Stage 3 \\
& PWR (UOX) & SFR (TRU/U, Th) & PWR (U-233/U) \\
\hline Thermal efficiency, \% & 100.0 & 100.0 & 100.0 \\
\hline Natural resource, t/GWt-yr & - & 4.41 & - \\
Th & 62.71 & - & - \\
U & & & \\
\hline Charge mass, t/GWt-yr & - & 4.41 & - \\
Th & - & - & 0.23 \\
U233+Pa233 & 7.30 & 2.14 & 6.41 \\
U (other than U233+Pa233) & 0.00 & 0.86 & - \\
TRU & & & - \\
\hline Discharge, t/GWt-yr & - & 4.15 & 0.02 \\
Th & - & 0.19 & 6.15 \\
U233+Pa233 & 6.82 & 1.94 & 0.09 \\
U (other than U233+Pa233) & 0.10 & 0.76 & 0.38 \\
TRU & 0.38 & 0.36 & - \\
FP & & & -0.20 \\
\hline Mass balance, t/GWt-yr & - & -0.26 & -0.26 \\
Th & - & 0.19 & 0.09 \\
U233+Pa233 & -0.48 & -0.10 & 0.38 \\
U (other than U233+Pa233) & 0.10 & 0.36 & \\
TRU & 0.38 & & \\
FP & & & \\
\hline
\end{tabular}

The power-sharing fraction of each stage was calculated to ensure TRU and U-233 mass balances between the stages. At the equilibrium state, the recovered TRU mass from stages 1, 2, and 3 should be balanced to the required TRU mass in stage 2,

where,

$$
F_{E L}^{1} \times R M_{T R U}^{1}+F_{L L}^{3} \times R M_{T R U}^{3}=F_{E L}^{2} \times \Delta M_{T R U}^{2},
$$

$F_{E L}^{i} \quad=$ power sharing fraction of stage $i$,

$\Delta M_{T R U}^{i}=F M_{T R U}^{i}-R M_{T R U}^{i}=$ external TRU feed for stage $i$,

$R M_{T R U}^{i}=\left(1-L_{\text {sep }}^{i}\right) \times D M_{T R U}^{i}=$ recovered TRU mass from stage $i$,

$F M_{T R U}^{i}=\frac{C M_{T R U}^{i}}{\left(1-L_{\text {fiel }}^{i}\right)}=$ TRU mass for fuel fabrication of stage $i$,

$D M_{T R U}^{i}=$ discharge TRU mass from stage $i$,

$C M_{T R U}^{i}=$ charge TRU mass to stage $i$,

$L_{\text {sep }}^{i} \quad=$ separation loss rate of stage $i$,

$L_{\text {fuel }}^{i} \quad=$ fabrication loss rate of stage $i$. 
Similarly, the recovered U-233 mass from stages 2 and 3 should balance the required U-233 mass in stage 3 ;

where,

$$
F_{E L}^{2} \times R M_{U / 3}^{2}=F_{E L}^{3} \times \Delta M_{U / 3}^{3}
$$

$$
\begin{aligned}
& \Delta M_{U 3}^{i}=F M_{U 3}^{i}-R M_{U 3}^{i}=\text { external } \mathrm{U}-233 \text { feed for stage } i, \\
& R M_{U 3}^{i}=\left(1-L_{s e p}^{i}\right) \times D M_{U 3}^{i}=\text { recovered U-233 mass from stage } i, \\
& F M_{U 3}^{i}=\frac{C M_{U 3}^{i}}{\left(1-L_{f i e l}^{i}\right)}=\text { TRU mass for fuel fabrication of stage } i, \\
& D M_{U 3}^{i}=\text { discharge U-233 mass from stage } i, \\
& C M_{U 3}^{i}=\text { charge U-233 mass to stage } i .
\end{aligned}
$$

In addition, the total fraction of electricity generation of each stage should be unity,

$$
F_{E L}^{1}+F_{E L}^{2}+F_{E L}^{3}=1 \text {. }
$$

Using the three Eqs (16), (17) and (18), the power sharing fractions for the different thermal efficiencies were calculated and the results are provided in Table A.4 and A.5. The power sharing fractions calculated by the mass balance equations are exactly the same to the values calculated by using the Eq (14)

(Compare power sharing fractions in Tables 1 and A.5).

Table A.4 Power Sharing Fractions with Original Thermal Efficiencies of 33.3, 40.0 and 32.4\%

\begin{tabular}{|l|r|r|r|}
\hline & Stage 1 & Stage 2 & Stage 3 \\
\hline Recovered $(R M)$ mass, t/GWe-yr & & & \\
TRU & 0.29 & 1.90 & 0.26 \\
U-233 & - & 0.48 & 0.07 \\
\hline External feed $(\Delta M)$, t/GWe-yr & - & 0.27 & - \\
TRU & - & - & 0.64 \\
U-233 & 11.9 & 50.1 & 38.0 \\
\hline Electricity sharing, \% & & & \\
\hline
\end{tabular}

Table A.5 Power Sharing Fractions with Thermal Power Generation

\begin{tabular}{|l|r|r|r|}
\hline & Stage 1 & Stage 2 & Stage 3 \\
\hline Recovered $(R M)$ mass, t/GWe-yr & & & \\
TRU & 0.095 & 0.758 & 0.085 \\
U-233 & - & 0.193 & 0.023 \\
\hline External feed $(\Delta M)$, t/GWe-yr & - & 0.107 & - \\
TRU & - & - & 0.206 \\
U-233 & 12.8 & 45.0 & 45.2 \\
\hline Electricity sharing, \% & & & \\
\hline
\end{tabular}

At the equilibrium state, the normalized mass flow data of each stage was calculated such that the total electricity capacity of the whole nuclear fleet becomes 100 GWe-yr or 100 GWt-yr. 
The mass flow data for stage 1 were obtained from

- Required natural uranium;

- Charge fuel (which is LEU);

- Loss in the fuel fabrication;

- Depleted uranium (DU) ;

- Product from separation;

- Loss in the fuel separation;

$$
\begin{aligned}
& M_{N U}^{1}=\bar{M}_{N U}^{1} \times E^{1}, \\
& M_{C F}^{1}=\bar{M}_{C F}^{1} \times E^{1}, \\
& M_{\text {loss,fuel }}^{1}=M_{C F}^{1} \times L_{f u e l}^{1}, \\
& M_{D U}^{1}=M_{N U}^{1}-M_{C F}^{1}-M_{\text {loss,fuel }}^{1}, \\
& M_{p}^{1}=d f_{p}^{1} \times\left(1-L_{s e p}^{1}\right) M_{D F}^{1}, \\
& M_{\text {loss, sep }}^{1}=M_{D F}^{1} \times L_{s e p}^{1},
\end{aligned}
$$

where

$\bar{M}_{N U}^{1} \quad=$ natural uranium mass to produce unit electricity in stage 1 ,

$E^{i} \quad=$ power generation from stage $i$, which is $100 \times F_{B L}^{i}$,

$\bar{M}_{C F}^{i} \quad=$ normalized charge fuel mass of stage $i$ (see Tables A.2 and A.3),

$M_{D F}^{i} \quad=$ discharge fuel mass from the stage $i$ (which is identical to $M_{C F}^{i}$ ),

$d f_{p}^{i} \quad=$ product-wise mass fraction of stage $i$ discharge fuel (see Tables A.2 and A.3).

The mass flow data for stage 2 were obtained from

- Charge fuel;

$M_{C F}^{2}=\bar{M}_{C F}^{2} \times E^{2}$,

- Loss in the fuel fabrication;

$M_{\text {loss, fuel }}^{2}=L_{\text {fuel }}^{2} \times M_{C F}^{2}$

- Product from separation;

$M_{p}^{2}=d f_{p}^{2} \times\left(1-L_{s e p}^{2}\right) M_{D F}^{2}$

- Loss in the fuel separation;

$M_{\text {loss sep }}^{2}=M_{D F}^{2} \times L_{\text {sep }}^{2}$,

- Required natural thorium; where

$M_{\text {Charge,Th }}^{2} \quad=$ thorium mass in charge fuel of stage $2\left(=c f_{T h}^{2} M_{C F}^{2}\right)$,

$M_{\text {Recovered,Th }}^{2} \quad=$ recovered thorium mass from stage $2\left(=d f_{T h}^{2} M_{D F}^{2}\right)$,

$c f_{T h}^{2} \quad=$ thorium mass fraction of stage 2 charge fuel (see Tables A.2 and A.3).

The mass flow data for stage 3 were obtained from

- Charge fuel;

$$
M_{C F}^{3}=\bar{M}_{C F}^{3} \times E^{3},
$$

- Loss in the fuel fabrication;

$M_{\text {loss, fuel }}^{3}=L_{\text {fuel }}^{3} \times M_{C F}^{3}$,

- Product from separation;

$M_{p}^{3}=d f_{p}^{3} \times\left(1-L_{s e p}^{3}\right) M_{D F}^{3}$

- Loss in the fuel separation;

$M_{\text {loss,sep }}^{3}=M_{D F}^{3} \times L_{s e p}^{3}$.

Using the equations, the normalized metal mass flow data of the primary heavy metal and fission products were calculated and the results are provided in Tables A.6 and A.7. In these tables, the signs (-) and (+) indicate the feed and production to or from each technology category, respectively.

For the given thermal efficiencies (i.e., 33.3\%, 40.0\% and 32.4\% for the first, second, and third stages, respectively), the fuel cycle option requires natural uranium and thorium quantities of 2,238.0 and 40.4 
tons, while the required natural uranium and thorium are 805.7 tons and 14.5 tons, respectively, for the thermal power generation case. Thus, the mass flow data for that case decrease uniformly to $36 \%$ of the original values, which is exactly the same as the value calculated by using the mass renormalization factor of Eq. (15), i.e., 0.36 (see Table 1 in the main body of the report). All other values in the Mass Flow Data table show the same renormalization value.

In this work, the renormalization formulas were validated only for the three-stage representative fuel cycle option for EG37. However, the formulas could be validated for other representative fuel cycle options by using the approach provided in this Appendix.

\section{Reference}

A.1 T. K. Kim, E. Hoffman, and T. A. Taiwo, “Completion of Fuel Cycle Data Package System Datasheets for 2013 Evaluation and Screening,” Argonne National Laboratory, ANL-FCT-333, May 2013. 
Table A.6 Normalized Mass Flow to Generate 100 GWe-yr with Original Thermal Efficiencies in FCDP System Datasheet (EG37)

\begin{tabular}{|c|c|c|c|c|c|c|c|c|c|c|c|}
\hline \multirow{2}{*}{\multicolumn{2}{|c|}{$\begin{array}{l}\text { Stage } \\
\text { Technology }\end{array}$}} & \multicolumn{3}{|c|}{1} & \multicolumn{3}{|c|}{2} & \multicolumn{3}{|c|}{3} & \multirow{2}{*}{ Total } \\
\hline & & Fuel & NPPT & Sep/WF & Fuel & NPPT & Sep/WF & Fuel & NPPT & Sep/WF & \\
\hline \multicolumn{2}{|c|}{ Electricity, GWe-yr } & \multicolumn{3}{|c|}{11.9} & \multicolumn{3}{|c|}{50.1} & \multicolumn{3}{|c|}{38.0} & 100.0 \\
\hline \multicolumn{12}{|c|}{ Feed or product of nuclear materials (metric ton) ${ }^{\text {a) }}$} \\
\hline \multirow{2}{*}{$\begin{array}{l}\text { Natural } \\
\text { resource }\end{array}$} & $\mathrm{U}$ & $-2,238$ & & & & & & & & & $-2,238.0$ \\
\hline & Th & & & & -40.4 & & & & & & -40.0 \\
\hline \multirow{6}{*}{$\begin{array}{l}\text { Products } \\
\text { from fuel } \\
\text { or NPPT } \\
\text { technology }\end{array}$} & DU & $1,976.9$ & & & & & & -37.5 & & & $1,939.4$ \\
\hline & Th & & & & 552.4 & -552.4 & & & & & 0.0 \\
\hline & U-233 b) & & & & & & & 26.7 & -26.7 & & 0.0 \\
\hline & $\mathrm{U}^{\mathrm{c})}$ & 260.5 & -260.5 & & 267.7 & -267.7 & & 753.6 & -753.6 & & 0.0 \\
\hline & TRU & & & & 107.2 & -107.2 & & & 0.0 & & 0.0 \\
\hline & DF & & 260.5 & -260.5 & & 927.3 & -927.3 & & 780.3 & -780.3 & 0.0 \\
\hline \multirow{5}{*}{$\begin{array}{l}\text { Products } \\
\text { from } \\
\text { Sep/WF } \\
\text { technology }\end{array}$} & Th & & & & -513.1 & & 514.1 & & & & 1.0 \\
\hline & $\mathrm{U}-233^{\mathrm{b})}$ & & & & & & 24.0 & -26.7 & & 2.7 & 0.0 \\
\hline & $\mathrm{U}^{\mathrm{c})}$ & & & 241.1 & -268.2 & & 240.7 & -717.6 & & 716.1 & 212.1 \\
\hline & TRU & & & 3.4 & -107.4 & & 94.2 & & & 9.9 & 0.1 \\
\hline & FP & & & 13.4 & & & 45.1 & & & 43.7 & 102.2 \\
\hline \multicolumn{2}{|c|}{ Sum (=Loss) ${ }^{d)}$} & 0.52 & & 2.61 & 1.86 & & 9.27 & 1.56 & & 7.80 & 23.6 \\
\hline
\end{tabular}

a) Mass flow in metric ton was normalized to produce $100.0 \mathrm{GWe}-y e a r$ from whole nuclear fleet. The signs (-) and (+) indicate the feed and production to or from each technology category, respectively.

b) U-233 and Pa-233

c) Uranium other than U-233 and Pa-233

d) Summation of each column indicates the loss from each technology per each stage. 
Table A.7 Normalized Mass Flow to Generate 100 GWt-yr (EG37)

\begin{tabular}{|c|c|c|c|c|c|c|c|c|c|c|c|}
\hline \multirow{2}{*}{\multicolumn{2}{|c|}{$\begin{array}{l}\text { Stage } \\
\text { Technology }\end{array}$}} & \multicolumn{3}{|c|}{1} & \multicolumn{3}{|c|}{2} & \multicolumn{3}{|c|}{3} & \multirow{2}{*}{ Total } \\
\hline & & Fuel & NPPT & Sep/WF & Fuel & NPPT & Sep/WF & Fuel & NPPT & Sep/WF & \\
\hline \multicolumn{2}{|c|}{ Electricity, GWt-yr } & \multicolumn{3}{|c|}{12.8} & \multicolumn{3}{|c|}{45.0} & \multicolumn{3}{|c|}{42.2} & 100.0 \\
\hline \multicolumn{12}{|c|}{ Feed or product of nuclear materials (metric ton) ${ }^{a)}$} \\
\hline \multirow{2}{*}{$\begin{array}{l}\text { Natural } \\
\text { resource }\end{array}$} & $\mathrm{U}$ & -805.7 & & & & & & & & & -805.7 \\
\hline & Th & & & & -14.5 & & & & & & -14.5 \\
\hline \multirow{6}{*}{$\begin{array}{l}\text { Products } \\
\text { from fuel } \\
\text { or NPPT } \\
\text { technology }\end{array}$} & DU & 711.7 & & & & & & -13.5 & & & 698.2 \\
\hline & Th & & & & 198.3 & -198.3 & & & & & 0.0 \\
\hline & U-233 ${ }^{b)}$ & & & & & & & 9.6 & -9.6 & & 0.0 \\
\hline & $\mathrm{U}^{\mathrm{c})}$ & 93.8 & -93.8 & & 96.1 & -96.1 & & 270.6 & -270.6 & & 0.0 \\
\hline & TRU & & & & 38.5 & -38.52 & & & 0.0 & & 0.0 \\
\hline & DF & & 93.8 & -93.8 & & 333.0 & -333.0 & & 280.1 & -280.1 & 0.0 \\
\hline \multirow{5}{*}{$\begin{array}{l}\text { Products } \\
\text { from } \\
\text { Sep/WF } \\
\text { technology }\end{array}$} & Th & & & & -184.2 & & 184.6 & & & & 0.4 \\
\hline & $\mathrm{U}-233^{\mathrm{b})}$ & & & & & & 8.6 & -9.6 & & 1.0 & 0.0 \\
\hline & $\mathrm{U}^{\mathrm{c})}$ & & & 86.8 & -96.3 & & 86.4 & -257.6 & & 257.1 & 76.4 \\
\hline & TRU & & & 1.2 & -38.6 & & 33.8 & & & 3.6 & 0.0 \\
\hline & $\mathrm{FP}$ & & & 4.8 & & & 16.2 & & & 15.7 & 36.7 \\
\hline \multicolumn{2}{|c|}{ Sum (=Loss) $\left.{ }^{d}\right)$} & 0.19 & & 0.94 & 0.67 & & 3.33 & 0.56 & & 2.80 & 8.5 \\
\hline
\end{tabular}

a) Mass flow in metric ton was normalized to produce $100.0 \mathrm{GWt}$-year from whole nuclear fleet. The signs (-) and (+) indicate the feed and production to or from each technology category, respectively.

b) U-233 and Pa-233

c) Uranium other than U-233 and Pa-233

d) Summation of each column indicates the loss from each technology per each stage. 